\title{
Investigation of the Diabetic Patients' Knowledge on Diabetes and the Role of Clinical Pharmacist in Providing Pharmaceutical Care to Them
}

\author{
Neda Taner', M. Eşref Tatıpınar²* Ayşe Nur Aydın¹, Gülden Zehra Omurtag² \\ 1 İstanbul Medipol University, Clinical Pharmacy, İstanbul, Turkey \\ 2 İstanbul Medipol University, Pharmaceutical Toxicology, İstanbul, Turkey
}

\begin{abstract}
Type 2 Diabetes is a common incurable metabolic disorder with worldwide increasing prevalence. International Diabetic Association noticed that there is a very fast and alarming increase in the worldwide prevalence of Diabetes. In 2012, diabetic population around the world has reached 371 million people. Untreated or undertreated Type 2 Diabetes does affect the quality of life of the patients both directly by symptoms and indirectly by short term and long-term complications. In addition to the direct effects of type 2 diabetes mellitus, affects the patient's life in a bad way, if the treatment process is not followed carefully, the quality of life of the patient will be reduced. At this point, clinical pharmacist has an extremely important role in determining and executing the correct clinical treatment. Besides that, the importance of the patient's level of knowledge about the disease and its impact on the treatment process is very important. The major goal of this thesis is evaluating the diabetic patients ' knowledge on diabetes and the effect of this point on treatment process. This study has been done in Merve Pharmacy of Muğla/Turkey between January and March of 2018. A questionnaire consisting of 20 multiple choice questions has been used to evaluate 50 participants who are clinically diagnosed diabetics. SPSS 23.0 statistical program was used for the statistical analysis of the data and the findings were evaluated at and $5 \%$ significance level. It has been statistically observed that knowledge levels of patients affected the treatment process. Recognizing the importance of this factor by clinical pharmacists and other health professionals will increase the training for diabetes and prevent the problems arising from the patient's low-level knowledge.
\end{abstract}

Keywords: Type 2 diabetes, Disease knowledge, Clinical Pharmacy

*Corresponding Author: M. Eşref Tatıpınar, e-mail: metatlipinar@medipol.edu.tr

Neda Taner ORCID Number: 0000-0002-6141-8676

M. Eşref Tatlıpınar ORCID Number: 0000-0001-8422-3188

Ayşe Nur Aydın ORCID Number: 0000-0003-4689-0574

Gülden Zehra Omurtag ORCID Number: 0000-0002-2018-9619

(Received 19 February 2020, accepted 02 March 2020) 


\section{INTRODUCTION}

Diabetes Mellitus (DM) occurs when insulin is below from normal levels or because of insulin resistance. It is a disease associated with disorders of carbohydrate, fat and protein metabolism, manifested by hyperglycemia. Today, DM is seen as an epidemic disease in most of developing and industrializing countries. ${ }^{1}$

Type-2 Diabetes Mellitus (T2DM) is a lifelong untreatable metabolic disease whose prevalence is increasing worldwide. International Diabetes Federation's current data has revealed that overall prevalence of diabetes mellitus in 2012 has reached to 371 million people and it still continues its increase. 480 million people died from diabetes mellitus and treatment cost of DM exceeds $\$ 471$ billion each year. ${ }^{2}$ the overall prevalence of diabetes is expected to increase by over $50 \%$ in the next 20 years. ${ }^{3}$

Number of patients who try to overcome the problems that caused from diabetes and diabetes-dependent complications is increasing. One of a major and worldwide economic burden for the governments is the annual cost of diabetes, which totally amounts of $\$ 825$ billion. According to a report from World Health Organization (WHO) in 2016, it is predicted that diabetes expenditures will continue to rise. ${ }^{4}$

In order to improve the quality of life and reduce the economic burden on the health system, studies involving the patient and the health counselor for disease prevention and health promotion are essential. These studies will contribute to the reduction of the above mentioned economic and social damages, as well as to improve patient's quality of life and drug applications.

\section{METHODOLOGY}

\section{Type and Model of Research}

This is a cross - sectional study in which patients are examined with data obtained in a short period of time.

\section{Location and Time of Research}

This study was carried out in Merve Pharmacy in Muğla between the months of January 2018 - March 2018.

\section{Universe and Sample}

Since the study was a cross-sectional type, it was evaluated over the sample without a universe calculation. The sample size of the study consists of 50 adult participants [19 female (38\%) and 31 male (62\%)] diagnosed with diabetes and, who were voluntarily participated in this research in January 2018 at Merve Pharmacy. 


\section{Data Collection Tool}

In this study, data were collected by survey method which consisted of 20 demographic questions about the characteristics and illness of the individuals (Appendix-1). Survey was applied by face-to-face interview method.

\section{Analysis Method}

IBM SPSS 23.0 program was used for data analysis. Descriptive analysis was performed by looking at the frequency (n) and percentage (\%) values of the participants' responses to the research questions. Chi-square test was used to analyze the relationship between the disease-related variables. The type of chi-square test was determined by examining theoretical frequencies and cell number which calculated for each well. According to this, Pearson Chi-Square test was used for tables larger than 2x2 and 2x2 tables with smallest theoretical frequency greater than 25, Yates' Chi-Square Test (Continuity Correction) for 2x2 tables with theoretical frequencies between 5-25 and Fisher's Exact Test for 2x2 tables with theoretical frequencies less than 5 . The findings were evaluated at $5 \%$ significance level with $\% 95$ confidence interval.

\section{Ethics Committee Approval}

This study approved by Istanbul Medipol University Non-Invasive Clinical Research Ethics Committee on 03/01/2018 with approval number of 37.

\section{RESULTS AND DISCUSSION}

Demographic Characteristics and Disease Information of Diabetic Patients were given in consequent tables and the results were discussed.

\section{Demographic Characteristics}

Table 1 indicates that the number and percentage distributions of patients in the study group regarding demographic characteristics and disease information. 
Table 1. Demographic Characteristics and Diseases of Participants

\begin{tabular}{|c|c|c|c|}
\hline & & $n$ & $\%$ \\
\hline \multirow{2}{*}{ Age } & $20-40$ & 2 & 4,0 \\
\hline & $>40$ & 48 & 96,0 \\
\hline \multirow{2}{*}{ Sex } & Female & 19 & 38,0 \\
\hline & Male & 31 & 62,0 \\
\hline \multirow{4}{*}{ BMI } & Overweight & 2 & 4,0 \\
\hline & Fat & 28 & 56,0 \\
\hline & Obese & 18 & 36,0 \\
\hline & Extremely Obese & 2 & 4,0 \\
\hline \multirow{2}{*}{ Diabetes Mellitus in family } & Yes & 30 & 60,0 \\
\hline & No & 20 & 40,0 \\
\hline \multirow{4}{*}{ Cigarette or alcohol } & None & 38 & 76,0 \\
\hline & Cigarette & 9 & 18,0 \\
\hline & Alcohol & 1 & 2,0 \\
\hline & Both & 2 & 4,0 \\
\hline \multirow{3}{*}{ Time to diagnose diabetes } & Newly diagnosed & 16 & 32,0 \\
\hline & $<=7$ Years & 12 & 24,0 \\
\hline & $>=7$ Years & 22 & 44,0 \\
\hline \multirow{2}{*}{$\begin{array}{l}\text { Regular blood sugar } \\
\text { monitoring at home }\end{array}$} & Yes & 34 & 68,0 \\
\hline & No & 16 & 32,0 \\
\hline \multirow{2}{*}{ Regularly doctor check-up } & Yes & 20 & 40,0 \\
\hline & No & 30 & 60,0 \\
\hline \multirow{2}{*}{ Fasting blood sugar } & $<110$ & 9 & 18,0 \\
\hline & $>110$ & 41 & 82,0 \\
\hline \multirow{5}{*}{ Frequent symptoms } & Polyuria & 25 & 50,0 \\
\hline & Polydipsia & 17 & 34,0 \\
\hline & Polyphagia & 3 & 6,0 \\
\hline & Breath smell & 2 & 4,0 \\
\hline & Late healing of wounds & 3 & 6,0 \\
\hline \multirow{2}{*}{ Concomitant disease } & Yes & 26 & 52,0 \\
\hline & No & 24 & 48,0 \\
\hline \multirow{2}{*}{ Frequent infection } & Yes & 16 & 32,0 \\
\hline & No & 34 & 68,0 \\
\hline \multirow{2}{*}{$\begin{array}{l}\text { Unexplained weight gain } \\
\text { or loss }\end{array}$} & Yes & 5 & 10,0 \\
\hline & No & 45 & 90,0 \\
\hline \multirow{3}{*}{ Nutrition and eating habits } & Not paying attention & 6 & 12,0 \\
\hline & Always pay attention & 16 & 32,0 \\
\hline & Sometimes pay attention & 28 & 56,0 \\
\hline
\end{tabular}




\begin{tabular}{llcc}
\hline \multirow{2}{*}{$\begin{array}{l}\text { Knowledge level about your } \\
\text { disease }\end{array}$} & I have no knowledge & 14 & 28,0 \\
\cline { 2 - 4 } & I have little knowledge & 9 & 18,0 \\
\cline { 2 - 4 } & I have a lot of information & 27 & 54,0 \\
\hline \multirow{3}{*}{ Applied medical treatment } & Insulin & 5 & 10,0 \\
\cline { 2 - 4 } & Oral antidiabetics & 37 & 74,0 \\
\cline { 2 - 4 } & Insulin + Oral antidiabetics & 8 & 16,0 \\
\hline \multirow{2}{*}{$\begin{array}{l}\text { Factors affecting your follow- } \\
\text { up and treatment }\end{array}$} & Yes & 25 & 50,0 \\
\cline { 2 - 4 } $\begin{array}{l}\text { Applied non-pharmacologic } \\
\text { methods }\end{array}$ & No & 25 & 50,0 \\
\hline \multirow{3}{*}{\begin{tabular}{l} 
Complications \\
\cline { 2 - 4 }
\end{tabular}} & Diet & 17 & 34,0 \\
\cline { 2 - 4 } & Nephropathy & 33 & 66,0 \\
\cline { 2 - 4 } & Hyperglycemia & 2 & 4,0 \\
\cline { 2 - 4 } & Diabetic foot & 10 & 20,0 \\
\cline { 2 - 4 } $\begin{array}{l}\text { Information from your } \\
\text { pharmacist }\end{array}$ & Other & 7 & 14,0 \\
\hline
\end{tabular}

According to table 1, 96\% of the participants are 40 years or older. As a gender, $38 \%$ of the participants are women and, $62 \%$ are men. In terms of body mass index, $56 \%$ of the participants were fat and $36 \%$ were obese. Diabetes is seen in the $60 \%$ of the patients' first-degree relatives. $76 \%$ of the participants stated that they do not smoke and/or drink alcohol. $44 \%$ of patients have diabetes for more than 7 years. While $68 \%$ of patients monitor their blood sugar regularly at home, $60 \%$ do not attend regular doctor control. The rate of patients with fasting blood sugar levels above 110 is $82 \%$. The most common symptoms in patients were polyuria (50\%) and polydipsia (34\%). $52 \%$ of patients have other diseases associated with diabetes, but $68 \%$ do not have frequent infections. $90 \%$ of the patients stated that there was no unexpected weight gain and weight loss. $56 \%$ of the participants stated that they sometimes pay attention to their nutrition and $12 \%$ did not pay any attention at all. $54 \%$ of the patients stated that their knowledge level about diabetes was high. Most of the patients used oral antidiabetic agents (74\%) and $66 \%$ of them stated that they were dieting and $34 \%$ exercising. All diabetic patients participating in the study stated that they were sufficiently informed by their pharmacists.

\section{Disease Information of Diabetic Patients}

In the below mentioned tables certain parameter findings were evaluated in terms of their in-group relationships. In the context of table 2, the structure of relationship titles exhibit the findings between "fasting blood sugar values and regular doctor checkup in diabetic patients"; "duration of diag- 
nosis of diabetic patients and knowledge level of diabetes" and, "diabetic patients' regular doctor visits and their knowledge levels".

Table 2. Certain Parametric Disease Information's of the Patients with the Interaction of Physicians

\begin{tabular}{|c|c|c|c|c|c|c|c|}
\hline & & \multicolumn{4}{|c|}{ Fasting Blood Sugar1) } & & \\
\hline & & \multicolumn{2}{|c|}{ Less than 110} & \multicolumn{2}{|c|}{ More than 110} & & \\
\hline & & $n$ & $\%$ & $n$ & $\%$ & Total & p \\
\hline \multirow{6}{*}{$\begin{array}{l}\text { Regular } \\
\text { Doctor } \\
\text { Check }\end{array}$} & Yes & 8 & 40 & 12 & 60 & 20 & $p<0.002^{\star *}$ \\
\hline & No & 1 & 3.3 & 29 & 96.7 & 30 & \\
\hline & Total & 9 & 18 & 41 & 82 & 50 & \\
\hline & & \multicolumn{4}{|c|}{ Knowledge Level About Disease ${ }^{2}$} & & \\
\hline & & \multicolumn{2}{|c|}{ Less } & \multicolumn{2}{|c|}{ More } & & \\
\hline & & n & $\%$ & n & $\%$ & Total & $\mathbf{P}$ \\
\hline \multirow{7}{*}{$\begin{array}{l}\text { Time to } \\
\text { Diagnose } \\
\text { Diabetes }\end{array}$} & Newly & 15 & 93.7 & 1 & 6.3 & 16 & $p<0,001$ \\
\hline & $\begin{array}{l}\text { Less than } 7 \\
\text { years }\end{array}$ & 4 & 33.3 & 8 & 66.7 & 12 & \\
\hline & $\begin{array}{l}\text { More than } 7 \\
\text { years }\end{array}$ & 3 & 13.6 & 19 & 86.4 & 22 & \\
\hline & Total & 23 & 46 & 27 & 54 & 50 & \\
\hline & & \multicolumn{4}{|c|}{ Knowledge Level About Disease ${ }^{3)}$} & & \\
\hline & & \multicolumn{2}{|c|}{ Less } & \multicolumn{2}{|c|}{ More } & & \\
\hline & & $n$ & $\%$ & $n$ & $\%$ & Total & $p$ \\
\hline \multirow{3}{*}{$\begin{array}{l}\text { Regular } \\
\text { Doctor } \\
\text { Control }\end{array}$} & Yes & 19 & 95 & 1 & 5 & 20 & $p<0,001$ \\
\hline & No & 4 & 13.3 & 26 & 86.7 & 30 & \\
\hline & Total & 23 & 46 & 27 & 54 & 50 & \\
\hline
\end{tabular}

1) Fasting Blood Sugar, Fisher-Exact Test, ${ }^{*} p<.05{ }^{* *} p<0,001$; 2) Knowledge Level about Disease, Pearson Chi-Square Test, ${ }^{*} p<0.05$, post hoc test with Bernoulli correction; 3) Knowledge Level About Disease, Yates' Chi-Square Test

The title rows of the table consist of three headings. These are: "Distribution of Fasting Blood Sugar Values of Participants According to Regular Doctor Check"; "Distribution of Diabetes Diagnosis Duration of Patients According to Their Knowledge Level" and, Distribution of Patients Going to Regular Doctor Control According to Their Knowledge Level.

In the first title row, "Findings on the Relationship between Fasting Blood Sugar Values and Regular Doctor Checkup in Diabetic Patients" were evaluated. Fisher-Exact Test was performed to analyze the relationship between fasting blood glucose levels and regular physician control. Information about the analysis is given in table. 
As a result of the analysis of this first part, a significant relationship was found between fasting blood sugar values and regular doctor control $(\mathrm{p}<0.05)$. Fasting blood glucose values of those who go to regular doctor control were lower than those who did not go. This suggests and can be concluded that regular doctor control helps patients to lower their blood glucose values.

In the second title row, "Findings on the Relationship between Duration of Diagnosis of Diabetic Patients and Knowledge Level of Diabetes" were assessed. Pearson Chi-Square Test was used to analyze the relationship between the duration of diagnosis of diabetes and the level of knowledge of the patients. Table 2, second title row gives information about the analysis.

As a result of the analysis, a significant relationship was found between the duration of diagnosis of diabetes and the level of knowledge about the disease ( $p$ $<0.05$ ). When this title row of table is examined, it can be concluded that people who have been diagnosed with diabetes long time ago, think that they have more information about diabetes than those who have been diagnosed with diabetes recently, which confirms that patients try to obtain more information about their illnesses during their illness.

In the third title row, "Findings about the Relationship between Diabetic Patients' Regular Doctor Visits and Their Knowledge Levels" were analyzed by Yates' Chi-square test.

As a result of the analysis, it was found that there was a significant relationship between going to regular doctor control and the level of knowledge about the disease ( $\mathrm{p}<0.05$ ). When the last title row of Table 2 is examined, it is seen that those who think that their knowledge level about the disease are high, go to the doctor control less than those who think that they are low. From this it can be concluded that as patients' knowledge of their illnesses increases, their tendency to go to a doctor's control decreases.

The last two tables referred other parametric findings such as:

Findings on the Relationship between Diabetes Mellitus and Knowledge Level about Diabetes Mellitus in Patients' Diabetic First-Degree Relatives

For analyzing the relationship between having diabetes and the level of knowledge about the disease in first-degree relatives, Yates' Chi-square test was performed. Table 3 provides information about the analysis. 
Table 3. Distribution of Having Diabetes in Patients' First-Degree Relatives According to Their Knowledge Level

\begin{tabular}{|l|l|c|c|c|c|c|c|}
\hline \multicolumn{2}{|c|}{} & \multicolumn{5}{|c|}{ Knowledge Level About Disease } & \multicolumn{2}{|c|}{} \\
\cline { 3 - 9 } \multicolumn{2}{|c|}{} & \multicolumn{2}{|c|}{ Less } & \multicolumn{2}{c|}{ More } & \multicolumn{2}{|c|}{} \\
\cline { 2 - 9 } & $\mathbf{n}$ & $\%$ & $\mathbf{n}$ & $\%$ & Total & $\mathbf{p}$ \\
\hline \multirow{3}{*}{$\begin{array}{l}\text { Diabetes in First- } \\
\text { Degree Relatives }\end{array}$} & Yes & 4 & 13.3 & 26 & 86.7 & 30 & $p<0,001$ \\
\cline { 2 - 9 } & No & 19 & 95 & 1 & 5 & 20 & \\
\cline { 2 - 9 } & Total & 23 & 46 & 27 & 54 & 50 & \\
\hline
\end{tabular}

As a result of the analysis, it was found that there was a significant relationship between the presence of diabetes in first degree relatives and the level of knowledge about the disease ( $p<0.05$ ). When Table 5 is examined, it is seen that people with diabetes in their first-degree relatives think that they have more information about their diseases than those who do not. It can be concluded that the probability of thinking that the patients have knowledge about the disease increases with the presence of diabetes in the first-degree relatives.

\section{Findings on the Relationship between the Diabetes Diagnosis Period of Diabetic Patients and the Presence of Other Diabetic-Related Diseases}

Pearson Chi-Square Test was used to analyze the relationship between the duration of diabetes diagnosis and the presence of other diseases accompanying diabetes. Table 4 gives information about the analysis.

Table 4. Distribution of Diabetes Diagnosis Periods According to the Presence of Other Diabetes-Related Diseases

\begin{tabular}{|c|c|c|c|c|c|c|c|}
\hline & \multicolumn{5}{|c|}{ Concomitant Disease } & & \\
\hline & & \multicolumn{2}{|c|}{ Yes } & \multicolumn{2}{c|}{ No } & & \\
\hline & $\mathbf{n}$ & $\%$ & $\mathbf{n}$ & $\%$ & Total & P \\
\hline \multirow{2}{*}{$\begin{array}{c}\text { Time to } \\
\text { Diag- } \\
\text { nose } \\
\text { Diabetes }\end{array}$} & Newly & 3 & 18.8 & 13 & 81.3 & 16 & $.000^{*}$ \\
\cline { 2 - 8 } & Less than 7 years & 8 & 66.7 & 4 & 33.3 & 12 & \\
\cline { 2 - 9 } & More than 7 years & 15 & 68.2 & 7 & 31.8 & 22 & \\
\hline
\end{tabular}

Pearson Chi-Square Test, ${ }^{*} p<0.05$

As a result of the analysis, a significant relationship was found between the duration of diagnosis of diabetes and the presence of other diseases accompanying diabetes ( $\mathrm{p}<0.05$ ). When Table 4 is examined, people with long-term diabetes have other diseases that accompany more diabetes than those with short-term diabetes. It can be concluded that as the duration of diabetes increases, there is an increase in the diseases accompanying diabetes. Post hoc tests again. 


\section{RESULTS AND DISCUSSION}

Diabetes is a chronic and metabolic disease which has a very high prevalence in Turkey and the world. In 2010, an average of 285 million people worldwide, 90\% of the type 2 diabetes mellitus was detected. This disease, which threatens the whole world, is expected to increase in the following years. While the current prevalence of the disease may indicate the severity of the problem, the number of patients is estimated to reach 439 million by $2030 .{ }^{5}$

Because it is a chronic disease that lasts for many years and carries the risk of various complications, it is very important that the patient is informed effectively about the disease, its complications and treatment in order to be able to carry out the treatment successfully. The fact that chronic diseases affect people in developing countries rather than people in developed countries reveals the importance of patient education. ${ }^{6}$

In our study, the level of knowledge of patients with type 2 diabetes was investigated, and the problems associated with this treatment were observed. The results of the face-to-face survey conducted with 50 patients diagnosed with type 2 diabetes in Muğla province were evaluated and it was aimed to draw attention to the importance of the counseling service that the patients received from the clinical pharmacist regarding their illness and treatment process. Thus, it is aimed to make approaches to improve the patient's level of knowledge and the quality of the consultancy service.

In 2000, Abdur Rahman A. Kurkuman examined the relationship between knowledge level and diabetes in 300 patients (116 (38.7\%) of those have type 1 diabetes and 184 (61.3\%) of those have type 2 diabetes) who applied to King Saud Hospital-Unaizah, Al-Qassim Saudi Arabia Diabetes Polyclinic for treatment of their diabetes. $28 \%$ of type 1 diabetes patients and $45.7 \%$ of type 2 diabetes patients were male. Patients were separated into 6 group considering education levels and their HbA1c levels were measured before and after information. Measurements showed a decrease in HbA1c levels. The result was determined to be due to the increase in educational level. ${ }^{7}$

In 2004, Ya-Chun Hsiao and Ming-Nan Chien conducted a study of 1195 patients with Type 2 diabetes who complained of hypoglycemia at Mackay Memory Hospital (Taitung, Taiwan), and observed that advanced age and low education were serious hypoglycemic risk factors for type 2 diabetes. ${ }^{8}$

Bener et al. worked with 338 diabetic patients with a mean age of $45.5 \pm 8.9$ years at Hamad State Hospital in Qatar. While 29.6\% of the patients were illiterate, $\mathbf{2 4 . 3 \%}$ were primary school graduates, $\mathbf{2 8 . 1 \%}$ were high school graduates, 
and the least proportion was $18 \%$ university graduates. In the analysis, risk factors such as smoking, obesity and hypertension as well as low education level have emerged as an important risk factor. ${ }^{9}$

In his study with 120 diabetic patients who were followed up and treated in the Diabetes and Endocrine Polyclinic of Haseki Training and Research Hospital in 2008, Doğan found a statistically significant difference in type 2 diabetes patients in terms of low and high education level, gender and diabetes age. He observed the positive effect of education and consciousness on patient treatment. ${ }^{10}$

Patient education level, which is one of the most important factors in the prevention of complications of type 2 diabetes, affects the level of knowledge about the disease and its complications. A study conducted by Batkın et al. In Tokat State and SSK Hospitals between October 4, 2003 and January 4, 2004, 74.4\% of the patients were women and $96.6 \%$ were 40 years or older. $58,4 \%$ were illiterate. It has been reported that patients with a high education level and training have a higher level of knowledge and awareness about the complications of diabetes. ${ }^{11}$ Öz conducted a study at Haydarpaşa Numune Training and Research Hospital Diabetes Polyclinic and private Hyperbaric Oxygen Therapy Center with 19-86 age range of 53 women (48.2\%), 57 (51.8\%) male, total 110 type 2 diabetic patients. When foot examination was performed, diabetic foot disease was found in $50.9 \%$ of the patients, while knowledge levels, behavior and attitudes of educated patients about the disease and complications were found to be better. ${ }^{12}$

In addition to patient education, counseling and follow-up by the clinical pharmacist is of great importance. In the study conducted by Yücel and Sunay, between May and August 2014 with 176 diabetic patients in Keçiören Training and Research Hospital Family Medicine Polyclinics for the diagnosis and followup of DM, $78.98 \%$ of the patients were female and $21 \%$ were male. Of these patients, $64.80 \%$ had no training in diabetes and $90.90 \%$ had no training in diabetic foot and foot care. It was found that diabetic patients did not receive training in diabetic foot and foot care and did not practice what they knew even if their knowledge was sufficient. ${ }^{13}$

Nural and Hintistan conducted a study with 568 patients with $54.1 \%$ male in 2015 and mean age was $64.10 \pm 12.06$. Of these patients, $29.7 \%$ were illiterate. $75.7 \%$ of these patients have chronic complications related with diabetic foot and, $33.8 \%$ have a history of foot wound. The $54.1 \%$ of the patients who participates the training course regarding diabetes, only $44.6 \%$ of them satisfied the education level they received as sufficient. Only $40.5 \%$ said that they were talking to them about the cause of foot wounds, while $81.1 \%$ stated that they 
wanted to get education about diabetic foot. Patient education in Turkey is ineffective and does not reach its purpose because generally they are carried out in crowded-places like polyclinics or bedside in clinics or because of individual barriers. At this point, the clinical pharmacist, who specializes in pharmaceutical and pharmaceutical care, can provide quality counseling by providing the necessary training and information. ${ }^{14}$

As a result of the research conducted by Norris et al., it was observed that as the duration of the interview between the participant patient and the trainer increased, HbA1 level decreased more. Each 23.6-hour interview was reported to cause a $1 \%$ decrease in $\mathrm{HbA} 1$ level. In the first follow-up after the trainings given to the patient, HbA1c ratio decreased by $0.26 \%$ compared to the control group, this rate increased to $0.73 \%$ at the end of 1-3 months follow-up, but again $0.26 \%$ decrease in the follow-up period over 4 months. ${ }^{15}$

The observations obtained in this study support the importance of patient followup as in our study. In addition to providing the necessary pharmaceutical care and counseling, the clinical pharmacist should also periodically monitor whether the information provided is implemented by the patient and follow a controlled treatment plan. The patient should not be left alone during the treatment process and make sure that he/she is aware of his/her illness and requirements.

Quality of life is reduced in patients with diabetes, and this may have negative reflections on the patient's mood. Akin's study with 162 Type 2 diabetes patients treated at Meram Training and Research Hospital was examined by correlation and regression analyzes. Based on the findings obtained, $76 \%$ of depressive mood was envisaged with cases like "Physical Function", "Role Restrictions Due to Physical Problems", "Mental Health", "Understanding the Disease”, "Results”, "Knowledge Level about the Disease" and "Desperate / Accusive Approach". ${ }^{16}$

Emotional coping with the disease has a major impact on patient well-being. In the study conducted by Saatçi and his colleagues, the relationship between treatment satisfaction and patient welfare was examined. While there was a direct correlation between treatment and well-being, treatment satisfaction was significantly correlated with educational status, glycemic control, and compliance with diet and physical exercise. ${ }^{17}$

In our study, 50 people with type 2 diabetes, aged between 36 and 77 years, 19 (38\%) were female and 31 (62\%) were male, participated in a face-to-face survey. In our questionnaire, 20 questions were asked in order to measure the level of knowledge and awareness of the disease and its effect on the treatment process along with quantitative data such as age, gender, fasting blood sugar, body mass index. 
When the body mass index of the participants is examined, it is seen that $56 \%$ are overweight and $36 \%$ are obese. Diabetes is seen in the first-degree relatives of $60 \%$ of the participants. $76 \%$ of the patients stated that they do not smoke and drink alcohol. $44 \%$ of the participants had diabetes for more than 7 years. While $68 \%$ of patients follow regular diabetes at home, $60 \%$ do not attend regular doctor control. The rate of patients with fasting blood sugar levels above 110 is $82 \%$. The most common symptoms in patients were polyuria (50\%) and polydipsia (34\%). 52\% of patients have other diseases associated with diabetes, but $68 \%$ do not have frequent infections. $90 \%$ of the patients stated that there was no unexpected weight gain and weight loss. $56 \%$ of the participants stated that they sometimes pay attention to their nutrition and $12 \%$ said they did not pay any attention at all. $54 \%$ of the patients stated that their knowledge level about diabetes was high. Patients stated that oral antidiabetic agents (74\%) were the most commonly used medical treatment methods, while $66 \%$ stated that they used diet and $34 \%$ exercise. All of the diabetic patients participating in the study stated that they were sufficiently informed by their pharmacists.

According to the data obtained, there was a significant relationship between fasting blood glucose values and regular doctor visits ( $\mathrm{p}<0.05)$. Fasting blood glucose levels of the patients who went to regular doctor control were lower than those who did not go to regular doctor control. From this, it can be concluded that regular physician control reduces patients' fasting blood glucose values. In their study of 367 diabetes patients, Ciechanowski et al. observed that compliance with treatment worsened with reduced communication between physician and patient. ${ }^{18}$ Likewise, the research conducted by Gherman et al. in 2011 revealed that patients who had a good and regular bond with healthcare workers and educators were better at following medical advice and contributing to the treatment process. ${ }^{19}$

In our study, a significant relationship was found between the duration of diabetes diagnosis and the level of knowledge of the patients ( $\mathrm{p}<0.05)$. It was found that patients who were diagnosed with diabetes long ago thought that they had more information than those who were diagnosed recently. This result leads us to conclude that patients are trying to obtain more information about their illnesses during their illness. However, in the study conducted by Özbaşaran et al. with patients with diabetes at Seferihisar State Hospital, there was no statistically significant difference between the duration of disease and knowledge ( $\mathrm{p}=0.217, \mathrm{p}>0.05) .{ }^{20}$

As a result of the analysis of our study, a significant relationship was found between the level of knowledge of the patients about the disease and regular 
doctor visits ( $\mathrm{p}<.05)$. It was found that people who thought that their knowledge level about the disease were higher went to the doctor's control less than those who thought that they were low. According to this result, patients' thinking about their knowledge about their illnesses may have led them to conclude that their self-care is sufficient and may have reduced their level of care for physician control. In a study of 225 patients with type 2 diabetes, Cho et al. divided the patients into 2 groups according to their duration of diagnosis. At the end of the training, they observed that duration of diabetes affects the effectiveness of diabetes education, lifestyle, and behavior change and glycemic control. This study, similar to our data, concluded that long-standing patients with type 2 diabetes may require more intensive and continuous support and counseling. ${ }^{21}$

Another data obtained in our study is a significant relationship between the presence of diabetes near the first degree and the level of knowledge about the disease ( $p<0.05$ ). It is seen that people with diabetes in their first degree relatives think that they have more information about their diseases than those who do not. Accordingly, it can be concluded that the probability of having information about the disease increases with the presence of diabetes in the first degree relatives. Severe complications and other factors that reduce the quality of life associated with the illness may be seen as a more manageable problem. In addition, the patient who has observed the diagnosis and treatment process near the 1st degree can act more knowledgeable and conscious in his / her treatment process. There is no study showing that diabetes patients with diabetes near the first degree have an easier treatment process. However, increasing the level of knowledge of patients with diabetes in their relatives increases good mood, which may facilitate the treatment process. Mete, in his study of diabetes patients with bad mood, exercise, adherence to medical nutrition therapy, such as difficulty in implementing measures related to the disease, said that this situation will adversely affect the course of the disease. ${ }^{22}$

At the end of our study, a significant relationship was found between the duration of diagnosis of diabetes and the presence of other diseases accompanying diabetes ( $\mathrm{p}<0.05$ ). Accordingly, people with long-term diabetes have other diseases that accompany more diabetes than those with short-term diabetes. It can be concluded that as the life expectancy with diabetes increases, there is an increase in the diseases accompanying diabetes.

Early diagnosis and treatment of diabetes should be taken as soon as possible with the precautions required by treatment and serious complications should be prevented. ${ }^{23}$ It can be said that the primary duty belongs to the patient as well as the clinical pharmacist. As the education, knowledge and awareness lev- 
el of the patient increases, the course of treatment may be positively affected. In February-April 2014, Tasyaka conducted with 360 diabetic patients at Aksaray State Hospital, he found that patients' compliance to treatment levels were related to health literacy and education level. ${ }^{24}$

In our study, blood glucose levels of the patients who were constantly under the control of the doctor improved and the treatment plan proceeded more accurately than those who did not go to the doctor. The clinical pharmacist must ensure that the patient understands the importance of doctor control, and that the physician, clinical pharmacist and patient are in full cooperation to ensure that the treatment plan is carried out correctly.

Our research has shown that people with diabetes have long thought to be knowledgeable. However, it was found that patients who thought they were very knowledgeable did not go to regular doctor control. Here, the difference between the patient's knowledge and thinking that he / she are knowledgeable should not be ignored. The person who will observe this difference and make the necessary counseling is the clinical pharmacist. The clinical pharmacist should closely monitor the treatment process and self-care competence, especially in patients with long-term diabetes, and provide the necessary instructions and training in collaboration with the doctor.

Our study has shown that comorbidities are more common in people with type 2 diabetes for a long time. Type 2 diabetes, can progress simultaneously with many chronic diseases and, with various complications, should be adequately informed and adequate care and counseling, should be provided by the clinical pharmacists.

As a result of our study, it was observed that patients who had at least one of their relatives diagnosed with diabetes previously thought that they were more knowledgeable about their diseases. It is understandable that our participants will take such a stand against the disease that has been experienced before. The patient can approach his / her knowledge with greater self-confidence and good mood. However, there is no evidence that patients who think they are knowledgeable are truly conscious. Moreover, the information obtained by the impressions of the patients may have affected them negatively and increased their fears about coping with the disease. It would be appropriate to carry out studies that measure the level of consciousness and monitor the compliance process of patients who have been diagnosed with diabetes before. In this way, the effect of the observations made by the patient on the treatment can be evaluated, the wrong information can be corrected by the clinical pharmacist, and the necessary interventions can be followed by a healthy treatment process. 


\section{REFERENCES}

1. Özdemir, I. Hocaoğlu, C. Tip 2 Diyabetes Mellitus ve Yasam Kalitesi Bir Gözden Geçirme. Göztepe Tip Dergisi, 2009, 24, 73-78.

2. Shao, H.; Chen, G.; Zhu, C.; Chen, Y.; Liu, Y.; He, Y.; Jin, H. Effect of pharmaceutical care on clinical outcomes of outpatients with type 2 diabetes mellitus. Patient Prefer Adherence, 2017, 11, 897-903.

3. Kleinberger, J. W.; Pollin, T. I. Personalized medicine in diabetes mellitus: current opportunities and future prospects. Ann. N. Y. Acad. Sci, 2015, 1346, 45-56.

4. Ocal, E. E.; Onsuz, M. F. Diyabet Hastaliginin Ekonomik Yuku, Halk Sağlığı Dergisi, 2o18, 3, 24-31.

5. Chen, L.; Magliano, D. J.; Zimmet, P. Z. The worldwide epidemiology of type 2 diabetes mellitus--present and future perspectives. Nat. Rev, Endocrinol. 2011, 8, 228-236.

6. T.C. Sağlık Bakanlı̆̆ı, T.S.H.G. and Müdürlüğü, Turkiye Diyabet Onleme ve Kontrol Programi. Eylem Plani, 2011.

7. Uddin, I.; Ahmad, T. J.; Kurkuman A. R.; Iftikhar, R. Diabetes Education: Its Effects on Glycemic Control. Ann. Saudi Med. 2001, 21, 120-122.

8. Hsiao, Y.; Chien, M. Severe Hypoglycemia in Type 2 Diabetes. J. Intern. Med. Taiwan, 2006, 17, 73-77.

9. Bener, A.; Zirie, M.; Al-Rikabi, A. Genetics, Obesity and Environmental Risk Factors Associated with Type 2 Diabetes. Croat Med J. 2005, 46, 302-307.

10. Dogan D., Tip 2 Diyabetli Hastalarda Egitim Duzeyi ile Diyabet Baslangic Yasi, Vucut Kitle Indeksi, HBA1C Duzeyi ve Mikroanjiyopatik Komplikasyonlarin Karsilastirilmasi. 2008.

11. Batkin, D.; Cetinkaya, F. Diabetes Mallitus Hastalarinin Ayak Bakimi ve Diabetik Ayak Hakkindaki Bilgi, Tutum ve Davranislari. Saglik Bilimleri Dergisi, 2005, 14, 6-12.

12. Goc, M.; Diyabetes Mellitus'lu Hastalarda Hastaligin Suresi, Hastalarin Ogrenim Duzeyi, Diyabetik Ayakla Ilgili Egitim Alma Durumu, Metabolik Degerlerin, Diyabetik Ayak Gelisim Riski ve Diyabetik Ayaktan Koruyucu Davranis Modelleri Gelistirmeye Etkileri. 2008.

13. Yucel, F.; Sunay, D. Diyabetik Hastalarin Diyabetik Ayak ve Ayak Bakimiyla Ilgili Bilgi. Ankara Med. J. 2016, 16, 270-284.

14. Nural, N.; Hintistan, S. Diyabetik Hastalarin Ayak Bakimiyla Ilgili Bilgi ve Tutumlarinin Incelenmesi. Anadolu Hemsirelik ve Saglik Bilimleri Dergisi, 2015, 18, 116-124.

15. Norris, S. L.; Lau, J.; Smith, S. J.; Schmid, C. H.; Engelgau, M. M. Self-Management Education for Adults with Type 2 Diabetes. Diabetes Care, 2oo2, 25, 1159-1171.

16. Akin A. I. Tip 2 Diyabet Hastalarinda Yasam Kalitesi, Hastalikla Ilgili Bilgi Duzeyi, Hastalik Algisi, Stresle Basa Cikma ve Depresyon. 2013.

17. Saatci, E. Psikolojik Tedavi Memnuniyeti. Health and Quality of Life, 2010. 8.

18. Ciechanowski, P. S.; Katon, W. J.; Russo, J. E.; Walker, E. A. The Patient-Provider Relationship: Attachment Theory and Adherence to Treatment in Diabetes. Am. J. Psychiatry, 2001, 158, 29-35.

19. Gherman, A.; Schnur, J.; Montgomery, G.; Sassu, R.; Veresiu, I.; David, D. How are adherent people more likely to think? A meta-analysis of health beliefs and diabetes self-care. Diabetes Educ. 2011, 37, 392-408.

20. Gungor, N.; Çeçen, D.; Özbaşaran, F.; Çakmakçı-Çetinkaya, A. Seferihisar Devlet Has- 
tanesindeki Diyabetes Mellitus'lu Hastaların Hastalıkları Konusundaki Bilgi Düzeylerinin Saptanması. Atatürk Üniversitesi Hemşirelik Yüksekokulu Dergisi, 2004, 7, 1-11.

21. Ko, S. H.; Park, S. A.; Cho, J. H.; Ko, S. H.; Shin, K. M.; Lee, S. H.; Song, K. H.; Park, Y. M.; Ahn, Y. B. Influence of the duration of diabetes on the outcome of a diabetes self-management education program. Diabetes Metab. J. 2012, 36, 222-229.

22. Mete, H. E. Kronik Hastalik ve Depresyon. Klinik Psikiyatri, 2oo8, 11, 3-18.

23. Olgun, N.; Ulupinar, S. Hasta Güçlendirme ve Diyabetli Bireyin Güçlendirilmesi. Marmara Üniversitesi Hemsirelik Yüksekokulu Hemsirelikte Egitim Anabilim Dal, 2016, 1, 1-16.

24. Taskaya, S. Diyabet Hastalarinin Tedaviye Uyum Duzeyleri ile Saglik Hizmeti Kullanimi ve Yasam Kalitesini Etkileyen Faktorler. 2014. 